\title{
The Remains of the Jew: Imperial Christian Identity in the Late Ancient Holy Land
}

\author{
Andrew S. Jacobs \\ University of California, Riverside \\ Riverside, California
}

While defending the veneration of relics against their Gallic detractor Vigilantius (who scorned such veneration as mere idolatry), ${ }^{1}$ monk and manof-letters Jerome described a charged moment at which a scriptural shade materialized dramatically into Christian perception:

Must now also Arcadius Augustus be considered sacrilegious, who after so long a time has transferred the bones of blessed Samuel from Judaea to Thrace? Must all the bishops be judged not only sacrilegious but idiotic, who carried that most vile thing, piles of ashes in silk and a golden vessel? Are the peoples of all the churches stupid, who rushed out to the holy remains, and received the prophet with such joy as if they perceived him to be present and living, when the swarms of peoples joined together, from Palestine all the way to Chalcedon, and shouted Christ's praises in a single voice? Truly they were adoring Samuel, and not Christ, whose priest (levita) and prophet Samuel was. ${ }^{2}$

Jerome's defense of Samuel's bones radiates down from the emperor Arcadius to all the churches of the East, creating a highway of sanctity from Jerusalem to Constantinople. For Vigilantius to condemn Jerome and Jerusalem, he must also condemn the emperor and Constantinople; likewise, for the emperors in the capital to claim religious dominion to complement their political authority, they must look to Jerusalem and acquire from there the relics of antiquity, like importing so much precious marble. The march of Samuel's bones is the triumphal procession of a Christian empire, and Jerusalem becomes simultaneously the site of imperial religious victory and a new epicenter of imperial piety, a quasi capital of the Christianized imperium.

Journal of Medieval and Early Modern Studies 33:1, Winter 2003. Copyright (C) by Duke University Press / 2003 / \$2.00. 
From the fourth century onward, Roman Palestine became the prime location for the production and dissemination of Christian relics, those bits of sanctity that could be uncovered, through arcane knowledge or divine revelation: bones, clothes, books, sometimes dirt and water over which saints were believed to have passed. ${ }^{3}$ Of course, the "cult of relics" was not limited to the holy land, or to relics deriving from the holy land. Peter Brown has focused his attention on the Western provinces to great effect. ${ }^{4}$ E. D. Hunt has pointed out, however, the ways in which relic production was in some ways the special privilege of Palestine. ${ }^{5}$ An apt comparison might be the sale in the United States of French champagne and California sparkling white wine. It is clear, in any case, that the rapid and profligate dissemination of relics from the holy land to other provinces of the Roman Empire made materially manifest the charged networks of political and religious authority and authenticity resident in the Christian city of Jerusalem. ${ }^{6}$ Relics also demonstrate how intimately interwoven were the material and intellectual practices of Christian empire-building from the holy city: for a relic to retain its cultural and religious value, it had to be authenticated, most often through elaborate telling and retelling of the story of its discovery. ${ }^{7}$

Time and again in these narratives of discovery (inventiones) we find inscribed the Palestinian Jew, the fitful emblem of "old" Jerusalem who served to channel the power dynamics of the newly imperial Christian city. ${ }^{8}$ These Jews were constant shadows of the conquered past in the "new" Christian Jerusalem, as Eusebius of Caesarea had noted when discussing Constantine's construction of the Church of the Holy Sepulcher:

So then on that very spot of salvific witness the new Jerusalem was raised up, facing opposite the famous one of old, which, following the foul pollution of the Lord's murder, had experienced the extremes of desolation, a judgment upon its impious inhabitants (dussēbōn oikētorōn). ${ }^{9}$

In the New Jerusalem those ancient and "impious inhabitants," the Jews, lingered in the imperial Christian imagination. Günter Stemberger, in his survey of archaeological and literary remains of the late ancient holy land, has pointed out the predominance of Old Testament and Jewish figures in Christian relic inventiones, and suggests that "a number of questions arise in this context: do these graves go back to Jewish tradition, are they found because of Jewish information, are there clashes between Christians and Jews in the 
fight for the possession of such sites?" 10 These options - seamless linear progression from "old Israel" to "new Israel" or fierce religious conflict between contentious "sister-religions" - both mask the political and social contexts in which Christians "invented" a tractable Jewish past and, indeed, risk replicating the very processes of conquest and appropriation that are embedded in the late antique discourses of relic invention. ${ }^{11}$

Consider again the image crafted by Jerome, of Arcadius bringing up the bones of Samuel from Jerusalem to Constantinople, and how carefully yet ambiguously Jerome has invoked the language of imperial triumph. ${ }^{12}$ As in classical Roman triumphs, we witness the imperial triumphator, Arcadius, his faithful army (the bishops), and the screaming throngs (populi, as Jerome appropriately calls them) cheering on his victory. We further witness their beloved prophet Samuel, yet here we might pause to consider: Does Samuel march in triumph with Arcadius, as his star general? Or is he rather the foreign spoil, the defeated barbarian king, whom Arcadius brings home to New Rome in chains ("silk and golden vessel")? This doubled vision of Samuel — at once spoil and spoiler — signals the particular ambivalence of this inscription of Christian imperial power.

I propose in this essay to examine some of the more popular narratives of relic discovery in the fifth and sixth centuries from the area of Jerusalem not as evidence for Christian supersession or Jewish-Christian "conflict," but rather as literary remains of a new, pervasive, and ambiguous discourse of Christian imperialism. ${ }^{13}$ While I agree with Stemberger and others that the predominance of dead Jews in Christian narratives of relic invention must tell us something, I suggest that we consider modes of authority and representation and the manner in which literary and material remains (reliquae) might be read as a chapter in the construction of a new Christian empire. In the circulation of relics and their stories that began to increase at the beginning of the fifth century, we see perhaps the ways in which the "others" of the past could be conjured up and absorbed into a new Christian self, the ways in which Christian empire could be built on the remains of the Jew.

To this end I shall make use of recent strands of postcolonial criticism, strategies for reading imperial and colonial texts that emphasize not only the brute exercise of power by one population over another, but the manner in which cultural and social practices both enact and disrupt such exercises of power. ${ }^{14}$ While I do not mean to imply the universal applicability of modernist historical categories and practices, as if ancient Palestine were somehow identical to the British Raj, I do propose that historians of 
premodern periods concerned with the ideologies and cultural practices of empires might learn analogically from diverse theoretical perspectives that attend (in other historical settings) to notions of culture, religion, politics, and power. ${ }^{15}$

For this purpose I suggest that we may read the late Roman Christian holy land as an instance of what Mary Louise Pratt has dubbed a "contact zone": "a social space ... where disparate cultures meet, clash, and grapple with each other, often in highly asymmetrical relations of domination and subordination." 16 Through attention to asymmetry, to shifting and diversely manifested power relations, we can perhaps begin to understand the complex processes through which Christian piety and Roman politics intertwined in the late antique and early medieval periods. Through readings informed by postcolonial criticism, I shall posit that the remains of the Jerusalem Jew in Christian thought and imperial practice were not merely univocal signs of the "other," always conquered and eliminated, lifeless trophies mounted on the wall. The remains of the Jew functioned rather as an open signifier of a new Christian identity emanating (in part) from the holy city of Jerusalem, a Christian identity that could not exist without the constant remastery and uneasy incorporation of a sacred and potent Jewish remnant.

\section{Judas and the True Cross}

From late antiquity through the Middle Ages, the most famous and paradigmatic holy land relic was the wood of the True Cross. Ritual and literary evidence survives from the second half of the fourth century describing Christian veneration of the Cross; the most vivid is perhaps the late-fourthcentury pilgrim Egeria's anecdote about the man who, in his zeal for a holy souvenir, "bit off and sneaked out a piece of the sacred wood."17 Pieces of the wood traveled throughout the Christian empire (presumably also through less furtive means), ${ }^{18}$ demonstrating the ability of holy-land relics to replicate themselves almost infinitely: as fragments were broken up, exchanged, and allotted to friends and family, these fragments rarely diminished the sanctity, quality, or even quantity of the original relic. ${ }^{19}$

As bits of the holy wood multiplied across the empire, so did the stories about how it came to be in Christian hands after three centuries of obscurity. ${ }^{20}$ In the earliest stories, circulating in the 390s and early 400s, Helena, mother of Constantine, discovers the site, which had been covered over by pagan temples, thanks to a "heavenly sign" (as we learn from Rufi- 
nus's early-fifth-century Church History). ${ }^{21}$ In other versions of the story, as that of Paulinus of Nola, Helena makes her discovery by interrogating the "most learned of the Jews" [de Iudaeis peritissimos] of Jerusalem, who have craftily concealed the location since the time of Jesus. ${ }^{22}$ The most elaborate narrative of the inventio crucis survives in a Syriac text that goes back to 500 C.E. ${ }^{23}$ Recent scholarship suggests this legendary account of Helena's journey to Jerusalem and her determined recovery of this most sacred relic of the Passion had its origins in Jerusalem, some time in the fifth century. ${ }^{24}$ It is a particularly rich and brutal story, in which the Empress Helena brings her full power and piety to bear on a subject population in Jerusalem in order to find the object of her quest. This most anti-Jewish of the inventio legends became the most popular throughout the Middle Ages, translated into diverse vernacular languages, and proliferating as profusely as the pieces of the True Cross themselves. ${ }^{25}$

According to this tale, upon her arrival in Jerusalem, Helena summons together all of the Jews remaining in the vicinity of the holy city (the text specifies "only 3,000") and berates the crowd several times about their faithlessness to Christ while demanding from them "experts in the law" so she might interrogate them. The crowd is winnowed down twice in this manner (from 3,000 to 1,000 to 500), and the Jews cannot figure out what the empress wants from them (Finding, 40, 58-60). ${ }^{26}$ Finally one of their number, appropriately named "Judas," 27 proposes an answer: "I think that she is using us to make an inquiry about the wood on which our forefathers crucified Jesus. But make sure that if one of us knows it, he does not confess. If he does, all feasts of our forefathers will cease and the Law will also be abolished" (40-42, 60). Judas here speaks as a resistant and loyal Jew, fearful for the annihilation of his people by the power of Jesus and seemingly unrepentant for the part Jews played in the Passion.

Judas's story becomes more complicated, however, when he reveals that his own family is descended from a group of Jews (including the protomartyr Stephen) who resisted the crucifiers of Jesus and, what's more, were crypto-Christians themselves. Judas's father on his deathbed had revealed their family's secret tradition, passed from father to son since the time of the Passion, and implored his son to follow in his own faith in Jesus as the Christ: "You, my son, do not revile Him and do not despise those who believe in Him; for you will have eternal life. If now, my son, in your days the Cross is searched for, show it" (Finding, 42, 62). As Judas relates all this to his fellow Jews, however, it is clear that his dying father was not particularly convincing: Judas does not want to tell the empress where the Cross is 
and so ensure the end of Jerusalem's Jews. Furthermore, he still identifies himself as one of those Jews whose "forefathers crucified Jesus."

Not until Helena threatens the remaining Jews with death by fire do they helpfully turn over Judas so he may reveal the location of the Cross. Even still Judas resists, stalling before the empress. Perhaps it is written down somewhere, he suggests. She demands to know where. He delays. She demands to be shown the location of Golgotha. He declares ignorance. The empress is fed up: " 'I swear by Christ, who was crucified, that I shall torture you with hunger and thirst until you tell me the truth.' And immediately she ordered him to be thrown into a dry well for seven days" (Finding, 44-46, 62-64). At the end of seven days Judas acquiesces, and the climactic revelation is achieved through the secret knowledge Judas received from his Hebrew ancestors in combination with his own pious prayers recited in Hebrew $(46,64)$. Judas is miraculously transformed by his own discovery into a faithful believer in Christ. He is placed in the care of the bishop of Jerusalem and, eventually, made into bishop himself under the name "Kyriakos" (48-50, 64-68). His particular knowledge as a Jew of Jerusalem has ended in facilitating his own rejection of "Jewish ignorance," as Judas later calls it $(50,68)$, and his transformation into the most pious and loyal of Christian bishops. His father's prophecy is brought to pass, as Helena "stirs up a persecution" against the remaining Jews and drives them out of "Jerusalem and from all of Judah" $(32,70)$.

As Jan Willem Drijvers has pointed out in his study of the legend and its significance, "The prominence of Judas is bound up with the message of the legend." 28 That message is in part one of imperial domination and cultural colonization that establishes a triumphant imperial Christian identity from the holy city of Jerusalem. Judas the local Jew serves as a focal point for the construction of imperial Jerusalem and the display of Christian dominion. Judas, at first along with the host of confused and harangued Jews of Jerusalem, acts as both the appropriate sign of authentication for the relic as well as an appropriate object of the relic's imperial power. Not only is the discovery made by the empress, it is made possible by her exertion of religious and political authority over the "natives" of Jerusalem. ${ }^{29}$ At the end of the story, one of Helena's final acts is to have Judas Kyriakos find the nails of the Cross, so that they can be made into a bridle for Constantine's horse (Finding, 50-53, 70-71). The story thus ends with the arming of the Roman emperor with Christian sanctity extracted from Jewish Jerusalem. ${ }^{30}$

Yet, at the same time that Judas is the conquered object of imperial majesty, he is also the new Bishop Kyriakos, willingly handing over his 
ancient Jewish secrets to his new Christian mistress. Judas Kyriakos is not simply overcome by a brute display of imperial might: he is also himself altered, absorbed into Christian subjectivity, transforming and transformed by the wood of the Cross. The ambiguity of his identity — super-Jewish son of crypto-Christian Jews, resistant Jewish sage become pious Christian bishop - signals the constant interpenetrability of those very religiopolitical categories that seem so overdetermined in narratives of Christian triumph over Jews. When Judas performs his second miraculous discovery (that of the nails of the Cross), he very consciously thinks back to his discovery of the Cross: "And he prayed for a long time and waited to see a sign like that former one" (Finding, 50,70-71, although it is not noted that he prayed in Hebrew this time). That is, he recalls the sign given to him when he was still a Jew, or not quite yet a Christian, or some unrecognizable blend thereofthe colonial hybrid, perhaps, about whom theorist Homi Bhabha writes: "the colonial hybrid is the articulation of the ambivalent space where the rite of power is enacted on the site of desire, making its objects at once disciplinary and disseminatory." 31 As both the object of imperial discipline and the agent of religious dissemination, Judas through the True Cross symbolizes not only the result of Christian imperial power, but its meandering processes. Judas the Jew is a "doubly inscribed figure [who faces] two ways without being two-faced." 32 The mutation of Judas from crafty "native" into pious bishop for that very reason alerts us that more than mere triumph is narrated by this text, more than a simple "replacement" of Jewish Jerusalem by Christian. The old city is not merely razed and built over, it is itself stratified, preserved, and incorporated into a new Christian landscape.

\section{Gamaliel and the bones of Saint Stephen}

Another tale of relic discovery from the environs of Jerusalem, from the beginning of the fifth century, makes similarly "doubled" use of the local Jew in order to inscribe authenticity and religious dominion into imperial Christian identity. In 415, a priest named Lucianus from the suburbs of Jerusalem had visions that supposedly led him to discover the bones of Stephen the first martyr. ${ }^{33}$ While he recorded his tale in Greek, we have extant two roughly contemporary Latin translations, designed to "travel" with the relics as pieces of Stephen made their way to various bishops across the Mediterranean. ${ }^{34}$ In Lucianus's report, we find again the deeply embedded "Jewishness" breaking through the foundations of imperial Christianity.

Lucianus recounts how the first vision came to him one night as he 
slept in his customary place in the baptistery of the church, keeping watch over the church vessels:

As if in a trance, and coming into semiconsciousness, I saw an old man with long white hair that was hieroprepe (that is, worthy of a priest), 35 having an abundant beard, decked in a white robe in which were set golden gems that had the sign of the holy cross on them. Holding a golden wand in his hand, he came and stood to my right; and the golden wand pulsed and three times he called my name, saying, "Lucianus, Lucianus, Lucianus!" (Revelation $3-5 ; R E B, 192)^{36}$

It turns out that this well-dressed and striking nocturnal visitor is none other than Gamaliel, "who reared the apostle Paul and taught him the Law in Jerusalem" (Revelation 9; REB, 195; cf. Acts 22:3). Gamaliel's appearance is clearly meant to be both otherworldly - thus the glowing golden wand and shining, gilded garments - and yet particularly Jewish: thus his abundant beard and his long, white "priestly" hair give his specter a certain aura of "the Old Law." 37

Like the inventio crucis, Lucianus's tale is framed in a straightforwardly anti-Jewish manner. ${ }^{38}$ Once Gamaliel has identified himself to the astonished priest, he gets straight to the reason for his nocturnal visitation: "With me, lying in the eastern part of the tomb, is my lord Stephen himself, who was stoned by the Jews (Iudaeis) and the princes of the priests in Jerusalem for his faith in Christ in public at the gate which is to the north which leads to Cedar" (Revelation 10; REB, 195).39 Gamaliel and Stephen are not alone in their final resting place: with them is Gamaliel's friend (or nephew, in one version) Nicodemus and his son Abibas. ${ }^{40}$ Nicodemus, we learn, converted soon after his encounter with Jesus (John 3),

and discovering this, the Jews removed him from his leadership and anathematized him and exiled him from the city. And this one, as he suffered persecution for Christ, I sustained him in my field and I supported him and I clothed him until the end of his life, and I entombed him honorably next to lord Stephen. (Revelation 13; REB, 198)

Abibas is not put into direct conflict with the Jews of Jerusalem as are Stephen and Nicodemus (and, implicitly, Gamaliel), but he is contrasted 
with other unbelieving Jews: his own mother and brother (Gamaliel's wife and son), Ethena and Selemias, about whom Gamaliel says reproachfully:

Now my wife Ethena and firstborn son Selemias who did not know to believe in Christ, they withdrew from us and were interred in his maternal holding which is called the holding of Capharselemia; since they were considered unworthy of our company. So that you might believe, when you begin to dig, you will find the place of my wife and son empty. (Revelation 15; REB, $201)^{41}$

The "empty space" of Jewish wife and son is, perhaps, that generative gap left between Jew and Christian in the complicated conversion of Jewish bones into Christian relics: the trace that must always remain to mark the conversion itself, to leave its imprint in the process of appropriation, the Jewishness that cannot and must not be totally eradicated.

Additional such traces are scattered throughout the text that both intensify and ameliorate the Jewishness of Gamaliel and his cryptmates, similar to the manner in which his long beard and priestly robes are juxtaposed with cross-engraved gems. For instance, Gamaliel's son Abibas, who was baptized shortly after Gamaliel himself, is described as a deuterōtēs tou nomou, which has been translated into Latin as "a repeater of the Law," a technicus terminus attested in third- and fourth-century texts that seems to signify the Aramaic term tanna. 42 Yet he is also interred with Gamaliel, Nicodemus, and Stephen because he was a "Christian neophyte" (Revelation 24; $R E B, 205)$, and in fact is described as having remained "immaculate from his mother's womb" until death (Revelation 24; REB, 204), an epithet surely more desirable for a fifth-century Christian ascetic than a firstcentury rabbi.

Likewise, place-names in the text are given by Gamaliel in the "local" dialect of Aramaic, translated for Lucianus's benefit into Greek. 43 When the bodies themselves are discovered in their respective coffins, an engraved marker indicates the names of the deceased in Hebrew words carved in Greek letters: "Celihel, which means God's crown (stephanus Dei), and Nasoam, which means Nicodemus, and Gamaliel” (Revelation 43; REB, 213-14). ${ }^{44}$ The complex layering of identities produces strangeness and familiarity at once, integrating the alterity and even enmity of the past (embodied by converted Jews) into the Christian present. Gamaliel, like Judas Kyriakos, can represent at once the Jewish past that has been mas- 
tered, as well as the Jewish past that has graciously ceded place and been absorbed into the Christian present.

This combination of foreignness and discovery is typical of colonialist discourses of appropriation, what Bhabha has called "the productive ambivalence of the object of colonial discourse - that 'otherness' which is at once an object of desire and derision, an articulation of difference contained within the fantasy of origin and identity." 45 The "fantasy" in the material construction of a Christian landscape through the discovery of relics appears in the collusion of the land's former "natives," who can both explain and mediate the otherness of the past. Lucianus introduces himself at the beginning of the text as a priest "in the town of Caphargamala in the territory of Jerusalem" [in villa Caphargamala in territorio Hierosolymum] (Revelation 1; REB, 190). The name of the town is manifestly foreign to its audience, neither Greek nor Latin; yet not until Gamaliel himself arrives do we discover that this is the name given to the land by Gamaliel himself, that it in fact means "Gamaliel's estate" [Caphargamala quod interpretatur villa Gamalielis] (Revelation 11; REB, 196). 46 Thus the visions from Gamaliel directing Lucianus and the bishop of Jerusalem to his tomb function in an almost testatory fashion: he wills his own property to the church of Jerusalem, providing the Christians of the Jerusalem territory with the fantasy of colonial natives graciously giving their land to imperial masters.

Soon after Lucianus's discovery, Stephen's bones traveled outward from Jerusalem, bearers of this new fantasy of imperial Christian domination stamped with the particular emphasis of Jerusalem. ${ }^{47}$ The relics and their authenticating story carried with them the fantasy of dominion and capitulation, exemplified most stunningly by their adventus on the island of Minorca, where their presence and power resulted in the forced conversion of the Jews there. ${ }^{48}$ The circulating narratives and bones of Saint Stephen and the True Cross provided imperial Christians with a new way of integrating the otherness of the past into a triumphant present, of more tightly linking the expressly imperial power of the court at Constantinople and the more subtle religious authority of the Christian capital of Jerusalem.

\section{Bones of the prophets}

The historian Sozomen, writing a few decades after Lucianus, produced two further inventiones in his Church History, both of which incorporate the remains of the Jewish past into the imperial Christian present. 49 The first inventio, of the minor prophets Micah and Habakkuk, comes into the his- 
torical narrative as Sozomen is describing the spiritual triumph of the church at the end of the fourth century. It was, he writes, a time in which "the church everywhere" was moved to follow the pious examples of their bishops and priests. The great piety of this age seemed confirmed when "Habakkuk, and not long after Micah, the first prophets, were brought to light" (Church History 7.29.1; GCS 50:345). The inventor is the "church administrator" of Eleutheropolis, Zebennos, who is guided to the bodies by "a divine vision of a dream." The tomb of Micah is even described as a sort of local "tomb of the unknown holy man": "those ignorant people (agnoountes) who live in the area call it 'Nephsameemana' in their native tongue (tềi patriōi phōnēi)," a title Sozomen plausibly translates from Aramaic into Greek as "tomb of the faithful" (Church History 7.29.2-3; GCS 50:345). The element of the native-as-strange transformed into the nativeas-familiar reappears through the linguistic registers of Aramaic and Greek and the knowledgeable appropriation of the sacred past from "ignorant" locals by "knowing" locals, such as Zebennos or Sozomen. ${ }^{50}$

Once the bodies have been recovered and restored (after some thousand years) to Christian worship, Sozomen gives a sufficiently imperial moral to the story. This anecdote of discovery and rightful appropriation is understood to validate the entire enterprise of Christian empire: "These events, which occurred during that reign, suffice for the greater glory (eukleian) of Christian teaching" (Church History 7.29.3; GCS 50:345). For Sozomen, the discovery of these ancient Jewish bones after centuries is a miraculous sign of favor from the Christian God. That such a prize site could remain covered over for so long, unrecognized by the (non-Christian?) locals, reinforces the rightness and propriety of the new Christian natives. By retrieving the "unknown prophets" from the hands of the (Jewish?) natives, Christian identity is once again ineluctably entangled with "the other" through an imperial discourse which "deterritorializes indigenous peoples, separating them off from territories they may once have dominated, and in which they continue to make their lives." 51 Rediscovery, as narrated triumphantly by Sozomen, is impossible without the reminder of Jewish forgetfulness. Jews must remain present, if evanescent, to reiterate Christianity's "greater glory."

The motifs of local ignorance, divine approbation, and Christian inheritance are reiterated in the last surviving chapter of Sozomen's history, the inventio of the bones of the prophet Zechariah. ${ }^{52}$ The setting is a small village, Kaphar-Zachariah, "in the territory of Eleutheropolis, in Palestine." The inventor this time is not a priest or bishop, but rather a tenant farmer 
named Kalemeros who, despite his unjust treatment of his fellow serfs, is visited by the prophet Zechariah in a dream and told where to dig (in a nearby garden) and what he will find (two coffins, a glass of water, and two harmless guardian snakes) (Church History 9.17.3; GCS 50:407). Once Kalemeros has followed these instructions, the prophet appears to him again, "wearing a tunic, wrapped in a white robe," which leads Sozomen to suppose "that he was a priest (hiereus)" (ibid.; the term hiereus used here may designate an Old Testament priest; cf. Jerome's description of Samuel as a levita, above). Besides the well-preserved body of Zechariah, there was also a child's skeleton lying outside the coffin, at the prophet's feet, clad in royal garments (ibid.). Sozomen reports that "the wise men and priests" were confused about who the child was and why he should have been buried with the prophet. In the inventio of Stephen the cryptmates of the protomartyr were introduced by Gamaliel himself to the visionary priest Lucianus; here the answer comes from another "local" source of verification that is now in the hands of knowledgeable "local" Christians. A monk (appropriately named Zechariah) produces an apocryphal Hebrew text that tells of the untimely demise of the favorite son of King Joash one week after Joash had Zechariah put to death (Church History 9.17.4; GCS 50:408).53 Thus a local farmer and an extracanonical (ou tōn ekklèsiazomenōn) Hebrew text act as the instruments of the Christian recovery of the bones of an Old Testament prophet, through the additional mediation of a local monk who bears the name of that prophet. We need look no further for a demonstration of the ways in which Christian identity became intricately layered with the shades of past and present, of appropriation and colonization, in the "discovery" of ancient Jewish bones by fifth-century Christians. Like Gamaliel, the Pharisee-turned-Christian, and Judas Kyriakos, the Jewish scholar-turnedbishop, Kalemeros and the Hebrew text act as "local witnesses," at once the subject and object of Christian power. ${ }^{54}$

\section{The old Jewish woman and Mary's robe}

Just as Samuel's bones burst forth triumphantly from Judaea to Thrace, so too did the power of these inventiones that so prominently featured Jewish characters. To consider the dissemination of this new religious discourse of power, I want to conclude by examining a narrative concerning the Virgin Mary's robe that circulated primarily in Constantinople. 55 This popular tale probably originated in the late fifth or early sixth century, and is not a Palestinian inventio (although it is set in Palestine). ${ }^{56}$ Nonetheless, the familiar 
pattern of hybrid "otherness" within the tale can gesture to the predominance of this new imperial Christian discourse beyond the fifth century.

The tale of Mary's robe recounts how two noble generals, Galbius and Candidus, having recently returned to the orthodox faith from the clutches of Arianism, made a fervent pilgrimage from the court at Constantinople to Jerusalem (Mary's Robe 2; Assomption, 294). ${ }^{57}$ Surprised en route by sudden nightfall, they take shelter at the hostel of "some old Jewish woman" [graus tis hebraia] (ibid.). ${ }^{58}$ The old Jewish innkeeper is, apparently, an entirely expected "native" element of the reconverted generals' Jerusalem pilgrimage. During their stay, the generals discover by chance a small back room, inside of which are "many sick people, men and women and children stretched out with different and varied illnesses and tormented by unclean spirits." They plot to discover what is going on, and "having considered wisely (sophoss) they invited the Jewish woman to dine with them so they might be able to figure out how to trick her as a lark (autèn chleuèi apatesai) and learn from her what was in that back room and how those sick and weak people stretched out in it were being healed." The generals, it appears, just want to have some fun with the locals.

At first the woman refuses to eat with them. She informs them solemnly that "we Jews eat things you Christians don't" (an interesting detail, since one assumes Jewish dietary restrictions would have restricted Jewish eating practices, not Christian ones). Galbius and Candidus insist that they are "honoring" her with their lofty company, and she acquiesces (Mary's Robe 3; Assomption, 296). They proceed to get her very drunk on "Jewish wine" [hebraikkou oinou] — the irony being, of course, that the old woman is done in by her own "Jewish food"-whereupon she reveals to them that she possesses Mary's last garment, given to the Jewish woman's ancestress (a servant) by the dying Virgin, and passed down through the generations. 59 Mary's deathbed robe possesses the power to heal and its fame has spread throughout Palestine (Mary's Robe 4-6; Assomption, 296-98). We should note here, however, that the robe's fame has not spread to Christians in Palestine, from whom the pilgrim generals Galbius and Candidus might have learned of it, only to Palestine's Jewish inhabitants. It is, like the tomb of the "unknown holy man" in Sozomen's tale, a historical monument waiting to be "re/discovered" by more proper inheritors. Upon learning of this treasure, the crafty noblemen beg permission to sleep in that back room and, during the night, they take measurements of the box in which the garment is kept. While accomplishing their pilgrimage in Jerusalem they have a duplicate box and robe fabricated (Mary's Robe 7-8; Assomption, 298). 
Upon their return, staying once more at the Jewish inn, they switch the boxes and sneak out before dawn with the sacred relic. The Jewish woman discovers what they have done only after the sick and dying in her hostel do not recuperate (Mary's Robe 9-10; Assomption, 298-300). The robe has, apparently, been promoted from healing in the backwater of Jewish Palestine to protecting the elites of Constantinople. In this narrative, told and retold in New Rome, we see a combination of elements familiar from the Palestinian inventiones: the knowledgeable Jewish native who conceals Christian secrets that are retrieved by an imperial hand through trickery and force. Yet the tenor of the discourse of inventio has shifted subtly, conforming to the political might of Constantinople and not the religious hybridity of Jerusalem. The Jews in this tale are utterly left behind - in fact, the Jews featured in the tale (an old Jewish woman and some ill Jewish locals) are presumably all but dead by the time Galbius and Candidus return to court at Constantinople. There is no mixture, no hybridization of desire and disdain, no point at which "they" are inextricably bound into "us." The power of New Jerusalem's discourse of Jewish "invention" has itself been once more transformed into the banner of imperial power waving from the battlements of New Rome. ${ }^{60}$

Christians in Jerusalem built their religious and political authority on the bones of martyrs, and on the fantasy of the cultural colonization of an ancient Jewish patrimony to which they had made themselves heirs. The stories attached to these relics, which authenticated their spiritual power, simultaneously underscored and masked the strangeness of these material and ideological acts of appropriation. Judas in the story of the True Cross or Gamaliel in the visions of the local priest Lucianus represented to the Byzantine Christian a new object of authority exercised by Christians in the fourth and fifth centuries. Jerusalem, with its shining new martyria and churches erected in the face of the devastated Temple Mount, made palpable for the Christians of empire this powerful paradox of otherness and sameness. The material and ideological construction of Christian Jerusalem points to what theorists call the hybrid nature of imperial discourse, which Robert Young describes as the "process in which the single voice of colonial authority undermines the operation of colonial power by inscribing and disclosing the trace of the other." 61 In Christian Jerusalem the trace of the Jewish other necessitated constant remastery and reconquest. This reconquest, however, evoked the paradoxical repetition of the threat of Jewish resistance. This constant remastery, this continuous process of appropriation, 
served to keep those "traces of the other" alive and potent in the landscape of Christian Jerusalem. Although Christians of the Roman Empire had built their identity on the remains of the Jew, the ambivalent nature of those relics and their stories would forever destabilize Christian Jerusalem, as Homi Bhabha suggests: "the jagged testimony of colonial dislocation, its displacement of time and person, its defilement of culture and territory, refuses the ambition of any total theory of colonial oppression." 62

\section{Notes}

I would like to thank Virginia Burrus, Daniel Boyarin, and the anonymous reader of JMEMS for their helpful comments and suggestions. I additionally benefited from a productive discussion of post/colonial theory at the 2001 Meeting of the "Models of Piety in Antiquity" group in Denver, Colorado. A shorter version of this paper was presented at the 2000 Annual Meeting of the American Academy of Religion. Unless otherwise noted, all translations are mine.

1 On the social context of this debate, see now David Hunter, "Vigilantius of Calagurris and Victricius of Rouen: Ascetics, Relics, and Clerics in Late Roman Gaul," Journal of Early Christian Studies 7 (1999): 401-30.

2 Jerome, Against Vigilantius 5. Text in Patrologia Latina (henceforth PL) 23:343B-C. Jerome employs a sort of geographical metonymy here, saying "Judaea to Thrace" and "Palestine to Chalcedon," when he seems to mean "Jerusalem to Constantinople." On Samuel's inventio, supposedly a few miles north of Jerusalem, see Pierre Maraval, Lieux saints et pèlerinages d'orient: Histoire et géographie des origines à la conquête arabe (Paris: Editions du Cerf, 1985), 269-71 and nn. 141-42. Against Vigilantius dates from 406 c.E.: see F. Cavallera, Saint Jérôme: Sa vie et son oeuvre, 2 vols., Études et Documents 1-2 (Louvain: Spicilegium Sacrum Lovaniense, 1922), 2:51-52.

3 See the classic study of Hippolyte Delehaye, Les origines du culte des martyrs, Subsidia Hagiographica 20 (Brussels: Société des Bollandistes, 1933), esp. 141-259; Maraval, Lieux saints, 29-50; and Günter Stemberger, Jews and Christians in the Holy Land: Palestine in the Fourth Century, trans. Ruth Tuschling (Edinburgh: T. and T. Clark, 2000), 105-15.

4 Peter Brown, The Cult of the Saints: Its Rise and Function in Latin Christianity, The Haskell Lectures on History of Religions, n.s. 2 (Chicago: University of Chicago Press, 1981).

5 E. D. Hunt, Holy Land Pilgrimage in the Later Roman Empire, A.D. 312-460 (Oxford: Clarendon Press, 1982), 128-54.

6 On "relic business" in the fifth century, see Michael Avi-Yonah, "The Economics of Byzantine Palestine," Israel Exploration Journal 8 (1958): 45-56.

7 A modern parallel might be the way in which the massive, multivolume Description de l'Égypte authenticated the Orientalized desires of Napoleonic and imperial France, 
desires made materially manifest by the "relic" of the obélisque displayed in the Place de la Concorde in Paris: see Edward Said, Orientalism (New York: Vintage Books, 1979), 84-88. On methods of discursive authentication of touristic signs, see Dean MacCannel, The Tourist: A New Theory of the Leisure Class (New York: Schocken Books, 1976), 109-23; and Jonathan Culler, "The Semiotics of Tourism," American Journal of Semiotics 1 (1981): 127-40. The authentication of touristic "markers" has been astutely applied to early Christian pilgrimage by Blake Leyerle, "Landscape as Cartography in Early Christian Pilgrimage Narratives," Journal of the American Academy of Religion 64 (1996): 127-28.

8 On the transformation of "old" Jerusalem into a Christian city, see Annabel Jane Wharton, Refiguring the Post Classical City: Dura Europos, Jerash, Jerusalem, and Ravenna (Cambridge: Cambridge University Press, 1995), 88-90; and John Wilkinson, "Christian Pilgrims in Jerusalem during the Byzantine Period," Palestine Exploration Quarterly 108 (1976): 75-101. For an overview of Christian imperial construction in Jerusalem, see Stemberger, Jews and Christians in the Holy Land, 48-120. Archaeological surveys of "Byzantine" building can be found in The New Encyclopedia of Archaeological Excavations in the Holy Land, ed. Ephraim Stern (Jerusalem: Israel Exploration Society, 1993), 2:768-85 (by Hillel Geva and Michael Avi-Yonah); and Oxford Encyclopedia of Archaeology in the Near East, ed. Eric Meyers (Oxford: Oxford University Press, 1997), 3:235-37; both supplementing Hugues Vincent and F.-M. Abel, Jérusalem: Recherches de topographie, d'archéologie et d'histoire, 2 vols. in 4 parts, Jérusalem nouvelle (Paris: Gabalda, 1912-26), vol. 2.

9 Eusebius, Life of Constantine 3.33. Text in Die Griechischen christlichen Schriftsteller (henceforth GCS) 7:99.

10 Stemberger, Jews and Christians in the Holy Land, 105. The idea that Christians merely "took over" an existing cult of tomb veneration from Palestinian Jews comes from the problematic work of Joachim Jeremias, Heiligengräber in Jesu Umwelt (Mt. 23, 29; Lk. 11, 47): Eine Untersuchung zur Volksreligion der Zeit Jesu (Göttingen: Vandenhoeck and Ruprecht, 1958), which builds on the titular gospel sayings to attempt to demonstrate a "cult of prophets" that preceded the Christian "cult of the saints." One of the primary sources for this argument, the so-called Vitae prophetarum, has recently been shown to belong to a Christian, Byzantine milieu: see David Satran, Biblical Prophets in Byzantine Palestine: Reassessing the "Lives of the Prophets," Studia in Veteris Testamenti Pseudepigrapha 11 (Leiden: E. J. Brill, 1995), 22-24, on Jeremias's use of this text and the subsequent assumptions made by scholars of the holy land.

11 The same masking of cultural imbalance may be found in certain historiographic treatments of early pilgrimage as well. See especially analyses of our earliest extant pilgrimage text, the Bordeaux Pilgrim's Travel Diary, in which the concerted attention to "Jewish heroes" (prophets, patriarchs, and other figures from the Hebrew Bible) is seen as evidence that the pilgrim had "Jewish guides" ( John Wilkinson, "Jewish Holy Places and the Origins of Christian Pilgrimage," in The Blessings of Pilgrimage, ed. Robert Ousterhout, Illinois Byzantine Studies 1 [Urbana: University of Illinois Press, 1990], 41-53) or was himself a "Jew who converted to Christianity" (Herbert Donner, Pilgerfahrt ins Heilige Land: Die ältesten Berichte christlicher Palästinapilger 
[4.-7. Jahrhundert] [Stuttgart: Verlag Katholisches Bibelwerk, 1979], 42). These options once more suggest either supersession or religious competition.

12 On late imperial triumphs, see Michael McCormick, Eternal Victory: Triumphal Rulership in Late Antiquity, Byzantium, and the Early Medieval West, Past and Present Publications (Cambridge: Cambridge University Press, 1986), esp. 36-64, on the fourth and fifth centuries. Arcadius had celebrated in Constantinople a triumph over the barbarian general Gainas in 400, six years before Jerome wrote Against Vigilantius: see McCormick, Eternal Victory, 49-51. Gainas, like Samuel, was a doubly ambiguous figure: a Gothic soldier who was appointed magister militum by Arcadius, attempted an unsuccessful uprising and occupation of Constantinople, and was assassinated by a Hun before being displayed as the spoils of the Emperor Arcadius's triumph.

13 Ora Limor, "Christian Sacred Space and the Jews," in From Witness to Witchcraft: Jews and Judaism in Medieval Christian Thought, ed. Jeremy Cohen, Wolfenbüteler Mittelalter-Studien 11 (Wiesbaden: Harrassowitz Verlag, 1996), 55-77, treats many of the same relic inventiones (as well as later stories from medieval Palestine), and concludes that "such legends serve a dual purpose. On the one hand they establish the authenticity of the traditions concerning the holy sites through the legitimation provided by the 'knowing Jew, and, on the other hand, they perpetually recreate the authority of the Jew and his Judaica Veritas" (77). She understands the "knowing Jew" to be essential and authoritative in Christian traditions, but does not, unfortunately, specify how Jews might have exerted or expressed such "authority" except abstractly.

14 For historical and critical introductions to postcolonial criticism, see the helpful volumes of Bart Moore-Gilbert, Postcolonial Theory: Contexts, Practices, Politics (London: Verso, 1997); and Ania Loomba, Colonialism/Postcolonialism, The New Critical Idiom (London: Routledge, 1998).

15 See Kathleen Davis, "National Writing in the Ninth Century: A Reminder for Postcolonial Thinking about the Nation," Journal of Medieval and Early Modern Studies 28 (1998): 611-37. I would like to thank the anonymous reader for this journal for encouraging me to elaborate this point further.

16 Mary Louise Pratt, Imperial Eyes: Travel Writings and Transculturation (London: Routledge, 1992), 4. See also p. 6 where "contact zone" is defined as "the space of colonial encounters, the space in which peoples geographically and historically separated come into contact with each other and establish ongoing relations, usually involving conditions of coercion, radical inequality, and intractable conflict."

17 Egeria's Travel Diary 37.2. Text in Sources Chrétiennes (henceforth SC) 296:286. For other fourth-century references to veneration of the Cross (or relics of the Cross), see Jan Willem Drijvers, Helena Augusta: The Mother of Constantine the Great and the Legend of Her Finding of the True Cross, Brill's Studies in Intellectual History 27 (Leiden: E. J. Brill, 1992), 95-100.

18 Fragments of the True Cross are mentioned in the possession of Macrina, sister of Basil of Caesarea (see Gregory of Nyssa, Life of Macrina 30; SC 178:240-42), Paulinus of Nola (see Paulinus of Nola, Letter 31.3-5; text in Corpus Scriptorum Ecclesiasticorum Latinorum [henceforth CSEL] 29:271-75), Melania the Elder, Sulpicius 
Severus, Georgian saint and imperial foster-child Peter the Iberian (Life of Peter the Iberian 23.21-24.3; references are to page and line numbers of the Syriac text in Petrus der Iberer: Ein Charakterbild zur Kirchen-und Sittengeschichte des fünften Jahrhunderts, ed. Richard Raabe [Leipzig, 1895]), and many other late ancient notables (see Hunt, Holy Land, 134 and nn.).

19 See Patricia Cox Miller, "'Differential Networks': Relics and Other Fragments in Late Antiquity," Journal of Early Christian Studies 6 (1998): 113-38. Miller notes that "the so-called 'cult' of relics ... [is] better described as an aesthetic in which division - the parceling-out of the bones, ashes, and other remains of the martyrs' bodies - was paradoxically also multiplication" (123), citing here Paulinus of Nola, Letter 31.6 (CSEL 29:274), on the miraculous "lack of diminution" of the wood of the True Cross.

20 Various attempts have been made by scholars to push the "real" inventio crucis back to the time of Helena. The main obstacle to this is the fact that Eusebius of Caesarea does not connect Helena to the Cross. For arguments that Eusebius deliberately suppressed mention of the Cross in sources relating to Helena and Jerusalem (except for a cryptic reference to "the token [ gnōrisma] of his holiness" in Eusebius, Life of Constantine 3.30.1; GCS 7:97), see Z. Rubin, "The Church of the Holy Sepulchre and the Conflict between the Sees of Caesarea and Jerusalem," Jerusalem Cathedra 2 (1982): 79-105; followed by H. A. Drake, "Eusebius on the True Cross," Journal of Ecclesiastical History 36 (1985): 1-22; and P. W. L. Walker, Holy City, Holy Places? Christian Attitudes to Jerusalem and the Holy Land in the Fourth Century, Oxford Early Christian Studies (Oxford: Clarendon Press, 1990), 245-80. Since these arguments rely on gaps and silences, they are essentially unprovable, although see Averil Cameron and Stuart G. Hall, Eusebius's Life of Constantine, Clarendon Ancient History Series (Oxford: Clarendon Press, 1999), 279-81 and 282-83. Medieval Christians in the East were also vexed by the problem of the wood's three-century hiatus from Christian worship, and developed an inventio crucis legend attached to the (fictitious) wife of Claudius, Protonike: see discussion in Drijvers, Helena Augusta, chap. 7.

21 Rufinus, Church History 10.7; GCS 9.2:969-70. Rufinus's story is similar to that of Milanese Bishop Ambrose, On the Death of Theodosius 42-48 (CSEL 73:393-97), whose version is probably the oldest we have.

22 Paulinus of Nola, Letter 31.5; CSEL 29:272. Sozomen, Church History 2.1.4, writing in the 440s, states explicitly that it was not due to "some ancestral text belong to a Jewish man (andros Hebraiou)" that Helena found the cross, but due to divine "signs and dreams" (GCS 50:48). For the assumption that Sozomen protests too much (evincing knowledge of the Judas-inventio crucis), see below.

23 The text of the "Judas Kyriakos" legend can be found in The Finding of the True Cross: The Judas Kyriakos Legend in Syriac, ed. H. J. W. Drijvers and Jan Willem Drijvers, Corpus Scriptorum Christianorum Orientalium 565, Subsidia 93 (Louvain: Peeters, 1997), henceforth cited as Finding with pages of the Syriac text and English translation. The authors postulate (25-27) that the legend was originally composed in or around Jerusalem, probably in Greek, and some time after the inventio of Stephen (in 415; see below). For analysis of this legend in comparison with other inventiones crucis, see Drijvers, Helena Augusta. 
24 See Drijvers and Drijvers, Finding, 20-25, who state that "modern research has made clear that a Jerusalem origin is obvious" (20), but suggests a little later, more moderately, that "it is most likely that the Kyriakos legend is of Jerusalem origin" (25). On the dating of the legend, see 20-22. As a terminus ante quem the authors point to Sozomen's overly strenuous objection to the fact that a Jew assisted in the recovery of the True Cross (see above), and as a terminus post quem they posit the dissemination of the Revelation of Saint Stephen (see below), which seems to have provided some narrative and symbolic inspiration for this inventio crucis. The earliest Syriac manuscript dates to about 500, providing an absolute terminus ante quem (especially if, as the authors suggest, the legend was originally composed in Greek).

25 See Drijvers, Helena Augusta, 165.

26 I cite from the Petersburg/Leningrad Syriac MS, which H. J. W. and J. W. Drijvers assume to be the oldest extant version (Findings, 31).

27 Both as the representative "Jew" (= Yehudah) and as the redeemer of Judas Iscariot's treachery (see ibid., 28-29).

28 Drijvers, Helena Augusta, 177.

29 Helena in these legends is generally entitled Augusta, emphasizing her close connection with the new Christian dynasty of Constantine. On connotations of her imperium/basileia, see Kenneth G. Holum, "Hadrian and St. Helena: Imperial Travel and the Origins of Christian Holy Land Pilgrimage," in Ousterhout, Blessings of Pilgrimage, 66-81.

30 This use of the nails is construed as a fulfillment of the prophecy of Zech. 14:20, also noted in other, earlier versions of the legend. See Drijvers, Helena Augusta, 112.

31 Homi K. Bhabha, "Signs Taken for Wonders: Questions of Ambivalence and Authority under a Tree Outside Delhi, May 1817," in The Location of Culture (London: Routledge, 1991), 113.

32 Homi K. Bhabha, "Sly Civility," in Location of Culture, 97.

33 The critical edition of the two Latin texts is found in S. Vanderlinden, "Revelatio Sancti Stephani (BHL 7850-6)," Revue des Etudes Byzantines 6 (1946): 178-217, henceforth cited as Revelation using Vanderlinden's paragraph numbers, followed by the journal (henceforth $R E B$ ) page numbers.

34 The intimate relation of traveling bones and text is explained in the prefatory letter written by a certain Avitus: "So there may be no doubt, I have also sent to you [with the bones] the very letter and description, copied out in my own handwriting, of that holy priest to whom this revelation was made, which, insofar as I faithfully desired and sought out the full knowledge of the truth, I dictated in his same Greek language, but which I later translated into Latin" (Letter of Avitus 9; REB, 189). Vanderlinden, "Revelatio," 186, concludes that version A of the text is Avitus's translation, while the fuller and less lacunate version B comes from "la version officielle de la lettre de Lucien, faite par ordre de l'évêque Jean [de Jérusalem]."

35 It is unclear what the term hieroprepees signifies here: in biblical Greek it just means "reverend," although apparently Avitus (or whoever translated version A) wanted to emphasize the "priestly" nature of the term, and thus gives it in Latin also as dignum sacerdotem (the word does not appear at all in version B). Since his beard and clothes are mentioned elsewhere, I take it as likely that the term, at least in Lucianus's original 
Greek, referred to the specter's venerable, "old-man" hair (a variant in several MSS reads geroprepen, that is, "fitting for an old man"). Stemberger, Jews and Christian in the Holy Land, 108, seems to think it indicates "priestly clothes" (in the German version, "Priesterkleidern"), which it might if hieroprepen is taken as a noun modified by longum, and not as an adjective modifying canum (along with longum). I have been unable to find any use of hieroprepees as a noun.

36 Version B reads: "As if in a trance, becoming slowly aware, I saw a man of old age, tall in stature, dignified expression, an abundant beard, girded in a cloak in which the lower part was interwoven as if with golden crosses (and he held in his hand a golden wand), shod in boots gilded on the surfaces, walking around and facing me in silence. When I saw this, doubting within myself I said, 'Who do you think this is? Does he come from God's side or the adversary's?' For I was not unmindful of the Apostle's words when he said, 'for even Satan transfigures himself into an angel of light.' [2 Cor. 11:4]. So when I saw him walking around I began to think to myself, 'If this man is from God, he will call my name three times in succession; but if he addresses me only once, I shall not answer him.' This one, without hesitation, instead of walking around, came toward me; while the wand in his hand pulsed, he shouted out my name three times, 'Lucianus, Lucianus, Lucianus!'” Version B is generally more descriptive than version $\mathrm{A}$, which was probably composed with more haste. Unless otherwise noted, I am citing from version A.

37 This "priestly Jewishness" is made explicit in Sozomen's account of an apparition of Zechariah (see below).

38 Version B, which Vanderlinden postulated was designed for the Jerusalem area, is most explicit about this, placing the following exclamation in the mouth of Bishop John of Jerusalem: "If these things are as you say, dearest one, just as you saw . . . it is fitting for me to transfer thence blessed Stephen the first martyr and archdeacon of Christ, who first waged dominical war against the Jews" [qui primus adversus Iudaeos dominica bella bellavit] (Revelation 34; REB, 209-11).

39 The gate "to Cedar" is not described in Acts 7 (the story of Stephen's stoning) and is a baffling toponym (see the note in Vanderlinden, "Revelatio," 196). Since Lucianus says it is explicitly the "northern" gate (in version A), he was possibly confusing Wadi Kitron (Septuagint kedrōn), mentioned as an eastern boundary of the city in, for instance, 2 Kings 23:4, with a metonym for the "cedars" (Septuagint kedroi) of Lebanon, thus "north." In any case, it is fair to say that, between Gamaliel's Aramaic, Lucianus's Greek, and the text's Latin, many linguistic idiosyncrasies inhere.

40 Interestingly, some modern scholars render the name of Gamaliel's son as Habib, the likely Hebrew or Aramaic original of the Grecisized Abibas (see, for instance, Maraval, Lieux saints, 45; and Delehaye, Origines, 80), as if to reinscribe the Hebraic quality of the family of Gamaliel, replicating the confusion and multiplicity of identities within the text itself.

41 This fuller description is from version B. Version A reads: "And my wife, who was called Ethna, and my firstborn son Selemias, since they did not know Christ's faith, were entombed in another estate of his mother, which is in Capharselemia" ( $R E B$, 200).

42 See, for instance, Jerome, Commentary on Habakkuk 1.12.15 (text in Corpus Chris- 
tianorum, Series Latina [henceforth CCL] 76A:610), a roughly contemporary reference to "a wise man who is called a deuterōtēs among them [i.e., the Jews]." On this phrase (also found in Origen's biblical commentaries), see Günter Stemberger, "Hieronymus und die Juden seiner Zeit," in Begegnungen zwischen Christentum und Judentum in Antike und Mittelalter: Festschrift für Heinz Schrechenberg, ed. DietrichAlex Koch and Hermann Lichtenberger, Schriften des Institutum Judaicum Delitzschianum 1 (Göttingen: Vandenhoeck and Ruprecht, 1993), 354-55; and Marcel Simon, Verus Israel: A Study in the Relations between Christians and Jews in the Roman Empire, 135-425, trans. H. McKeating, The Littman Library (Oxford: Oxford University Press, 1986), 88-91, on the terms deuterōtai and deuterōsis (possibly "mishnah").

43 Such as the northern part of Gamaliel's estate where the remains are found, called "in Syriac Dabatalia which means in Greek Andragathon" (Revelation 36; REB, 210). This emphasis on linguistic authenticity is compounded when Avitus (and the translator of version B) adds a further Latin gloss.

44 The late Hebrew/Aramaic words kālîl and nāsah 'am are literal translations of the Greek names stephanos and nikodèmos ("crown" and "the people conquers"). Note that Gamaliel is already sufficiently Hebrew not to require this sort of trilingualization.

45 Homi K. Bhabha, "The Other Question: Stereotype, Discrimination, and the Discourse of Colonialism," in Location of Culture, 67 (emphasis in original).

46 Version B uses the more technical legal term possessio.

47 In both versions of the Revelation there is a final vision in which Lucianus is made to give the "greatest plow-ox" he finds in Caphargamala to Bishop John of Jerusalem, while keeping for himself "the cart." In version B (what Vanderlinden takes to be the "official" Jerusalemite version), there is a telling explanation for this vision: "For I understood that saint Stephen himself was that great ox and that those carriages about which he spoke were the holy churches, and that Zion the first church itself was the greatest carriage" (Revelation 32; REB, 207).

48 See Severus of Minorca: Letter on the Conversion of the Jews, ed. Scott Bradbury, Oxford Early Christian Texts (Oxford: Clarendon Press, 1996); and now also the discussion of Daniel Boyarin, "Inventing Religion: Heresiology, Conversion, and Judaism around the Turn of the Fifth Century," a chapter from his forthcoming (tentatively titled) Making a Difference; or, Heresiology, Christianity, Judaism in Late Antiquity. I thank Professor Boyarin for sharing this work-in-progress.

49 On the "genre" of inventiones, see Maraval, Lieux saints, 41-47. But it should be noted that many of his examples from which he attempts to draw " 'règles' d'une méthode d'invention" (43) come from after the dissemination of the text of Lucianus (in Latin and Greek), and must surely rely stylistically on this "bestseller" of relic stories. Even the inventiones crucis, which surpassed the inventio Stephani in popularity in the Middle Ages, bear resemblance to the narrative of Lucianus that leads H. J. W. and J. W. Drijvers, Finding, 21-22 and 25, to assume some literary dependency. Sozomen came from Palestine and perhaps incorporates "local" legends not found in his major source, the historian Socrates. See Glen Chesnut, The First Christian Histories: Eusebius, Socrates, Sozomen, Theodoret, and Evagrius, 2nd ed. (Macon, Ga.: Mercer University Press, 1985), 200-202, on Sozomen's background and career at Constantinople. 
50 The name Zebennos sounds more Aramaic than Greek, perhaps related to the verb zaban "to sell." The story may thus contrast the "good" Christian native bishop with the "bad" ignorant (presumably non-Christian) natives who do not recognize the grave.

51 Pratt, Imperial Eyes, 135, speaking of nineteenth-century tendencies to impose "landscape" and archaeological "discovery" on territories such as Egypt and South America. See also p. 134: "To revive indigenous history and culture as archeology is to revive them as dead. The gesture simultaneously rescues them from European forgetfulness and reassigns them to a departed age" (author's emphasis).

52 In the preceding chapter, Sozomen promised to relate the inventiones of Zechariah and Stephen (Church History 9.16.4; GCS 50:407), but the extant history ends with a description of Zechariah's corpse. It is unclear whether Sozomen changed his mind, or never completed the history to his satisfaction, or ended up deliberately excising the ending to appease anti-Eudocia factions at the court of Constantinople, or perhaps even died before completing the history. See, in general, Chesnut, First Christian Histories, 203-4 and n. 20.

53 See 1 Chron. 24:20-23: "King Joash did not remember the kindness that Jehoiada, Zechariah's father, had shown him, but killed his son. As he was dying, he said, 'May the Lord see and avenge!'” (NRSV). Of course, all of this depends upon a common confusion between Zechariah son of Jehoiada in 1 Chronicles and the minor prophet Zechariah son of Berechiah (or son of Iddo). Cf. Luke 11:51 with Matt. 23:35, and the similar confusion with the father of John the Baptist (also Zechariah) in the account of the Bordeaux pilgrim (Bordeaux Pilgrim's Travel Diary 589.7-591.7; CCL 175:14-16).

54 See Stemberger, Jews and Christians in the Holy Land, 113.

55 I would like to thank George Demacopolous and Stephen Shoemaker for first drawing these stories to my attention. Greek text and French translation are from Antoine Wenger, L'assomption de la T. S. Vierge dans la tradition byzantine du VIe au Xe siècle: Études et documents, Archives de l'Orient Chrétien 5 (Paris: Institut Français d'Études Byzantines, 1955), 294-311; henceforth cited as Mary's Robe followed by page number in Wenger (Assomption). Most study has focused on the seventh-century versions of this narrative, revised in light of the Avar attacks on Constantinople in the 620s. See, for instance, Averil Cameron, “The Virgin's Robe: An Episode in the History of Early Seventh-Century Constantinople," Byzantion 49 (1979): 42-56.

56 See discussion in Wenger, Assomption, 111-36.

57 Citations refer to the longer version, which Wenger believes to be the earliest witness to the legend. Galbius and Candidus seem to have been "persuaded" into the orthodox fold by the execution of some Arian relatives, establishing from the outset the normative brutality of Orthodox Constantinople (Mary's Robe 1; Assomption, 294).

58 She is also called Ioudaia gune.

59 Both the drunken ploy of the noble generals and the lowly status of the innkeeper's ancestor were "edited" out by subsequent narratives. See the discussion in Wenger, Assomption, 128-32.

60 See Edward Said, "Traveling Theory," in The World, the Text, and the Critic (Cam- 
bridge, Mass.: Harvard University Press, 1983), 226-47, on the manner in which discourses move from one cultural site to another.

61 Robert J. C. Young, Colonial Desire: Hybridity in Theory, Culture, and Race (London: Routledge, 1995), 23.

62 Homi K. Bhabha, "Interrogating Identity: Frantz Fanon and the Postcolonial Prerogative," in Location of Culture, 41. 